\title{
What can Africa Learn from China's Experience in Agricultural Development?
}

\author{
Li Xiaoyun," Tang Lixia, Xu Xiuli, Qi Gubo and Wang Haimin
}

\begin{abstract}
Recently there has been a growing interest in China's rapid economic growth, particularly concerning the role of agriculture and its impact on poverty reduction. While China and Africa have developed their agricultural sectors under different historical conditions, this article proposes that China's poverty reduction and smallholder-based agricultural policies can provide a useful model for African countries to develop their own strategies in agrarian change.
\end{abstract}

\section{Introduction}

Since the 1980s, poverty levels have not changed in sub-Saharan Africa and the incidence of poverty remains higher than 40 per cent.

Agricultural productivity in both land and labour terms in sub-Saharan Africa has been stagnant since the 1970 s, and over the last 40 years, subSaharan Africa has become a net importer of agricultural commodities and staple foods.

Consequently, the literature on African agriculture has been largely pessimistic, and despite some more nuanced assessment in recent years, 'Agro-Afro-pessimism' continues to permeate the policy discourse (Oya 2010).

By contrast, in China, during almost the same time period, and particularly from 1978-2009, China's agriculture grew at an annual average rate of 4.5 per cent, total grain output at 2.4 per cent and population at 1.07 per cent. Agriculture and total grain output consequently outpaced population growth, which enabled China to feed a population accounting for 20 per cent of the world's total from its limited arable land (11 per cent of the world's total) using water resources equivalent to 25 per cent of the world average (Huang 2008). The steady growth in agriculture and rural economy has been an important contributor to reducing China's rural poverty (Li et al. 2010; Ravallion 2009; World Bank 2007).

The experiences and lessons of agriculture-led growth and poverty reduction in China have naturally attracted the attention of sub-Saharan
Africa and the international community (CDSG 2011). However, we should be cautious in drawing on the experiences of China's growth and poverty reduction strategies more broadly, given the two very different contexts. China has been a unified country despite its cultural diversity and vast territory, while Africa is a continent of 55 countries with diversified social, economic and environmental conditions. However, Africa can certainly draw experiences on how smallholderbased agriculture in China has been developed, and at the same time learn lessons on the range of problems associated with China's agricultural development - such as the emergence of an unequal society with a strong urban-rural divide, unclear land rights for farmers and highly intensive farming, leading to pollution and the degradation of natural resources.

This article intends neither to compare agricultural development in China and Africa, nor to analyse China's agricultural experiences, but to highlight some of the key conditions that enabled China to achieve its success in agricultural development and poverty reduction and to relate these where possible to the African context. This requires a clear account of the Chinese experience which, although unique in many ways, still affords some interesting potential examples for sustainable agricultural development in many parts of Africa. After briefly discussing the historical conditions that both China and Africa inherited, the article focuses on agricultural policy processes in China and Africa. 
In conclusion, there is a focus on smallholder agriculture, arguing that this structural feature of the Chinese model has the most promise for African rural and agricultural development.

\section{Historical conditions for agricultural development in China and Africa}

The origin and evolution of Chinese agricultural structure has been based on long-term experimentation over thousands of years. This has enabled Chinese smallholders to develop smallholder-based farming technology in an incremental way over a long period, and has provided a solid foundation for further agricultural development. Due to a steady increase of population over time in China, agriculture has been developed largely based on land-saving systems that focus on intensive farming such as poly-culture and inter-cropping. Under a decreasing land/population ratio, agricultural technology has been developed focusing on land productivity improvements. China's food crop yield already reached 2.75 tonnes per hectare in the eighteenth century, which is higher than present levels in Africa (Wu 1988).

In Africa, by contrast, a much less intensive form of agriculture evolved, making use of larger land areas. Currently less than 30 per cent of the potential arable land is under cultivation in sub-Saharan Africa. In Zambia, for example, 58 per cent of the land is suitable for cultivation, but only 14 per cent of the land is utilised; and in Mozambique the cultivated land only accounts for one fifth of the total potential arable land area (Li et al. 2010). Incentives for investment in productivity-enhancing technologies have been relatively low. Consequently, some parts of subSaharan Africa face the paradox of abundant land available and food insecurity, although in areas of high population density patterns of intensification are observed ( $c f$ Adams and Mortimore 1997; Tiffen et al. 1994).

In China, smallholder farmers have accumulated rice- and wheat-based farming technology providing a basis for modern technological innovation. In Africa, due to the impact of colonialism, technological change was mainly concentrated on cash crops and large commercial farms, rather than smallholder farming. This different pattern to some extent explains why the wheat- and rice-based green revolution of the 1970s and 1980s 'bypassed Africa' (Baum and
Lejeune 1986), but happened in China. This historical learning process in China and Africa suggests that the countries with a majority of smallholders require consistent smallholderbased agricultural structures that allow smallholders to accumulate and improve farming practices based on their individual contexts.

\section{Agricultural policy in China and Africa}

Agricultural growth in China after the end of the 1970s is well recognised. In fact, agriculture from the 1950 s to the 1970 s had also been significant despite the interruptions during the 1960s and 1970 s due to natural disasters and political struggle. 'Taking agriculture as the country's economic base' has always been a central element of China's development strategy since the 1950s. Within this strategy, food crop production has been the priority and land reform the major policy implemented. Before 1950, landlords only comprised 10 per cent of the rural population, but occupied 80 per cent of the arable land (Deng 1984). The Land Reform Act of P.R. China was passed in 1950 to distribute arable land to all peasants in private ownership. Three million peasants were given land, accounting for a total of 46.67 million hectares (Deng 1984). The land reform was also accompanied by policies which saw the establishment of agricultural universities, the development of national and local research institutions and the development of agro-input industries. These initiatives led to a dramatic increase in agricultural production, particularly in food crops.

From 1949-58, the output of food crops increased from 113.18 million tons to 197.65 million tons and average output of food crops per capita went from $208 \mathrm{~kg}$ to $299 \mathrm{~kg}$ in the same period.

Although agricultural production was negatively affected by both the Great Leap Forward Movement initiated in 1958, and the collectivisation movement from the 1960 s - the grain crop production dropped from 197.65 million tons in 1958 to 154.41 million tons in 1962 - crop production increased again after 1963, even though collectivisation was still in place with no direct incentive for farmers. Food crop output increased from 187.50 million tons in 1964 to 304.77 million tons in 1978 (NBSG 1999).

The steady increase in food crop production based on productivity improvements had been the result of a consistent agricultural development strategy 
in which food crops were prioritised. Packaged measures such as irrigation development, enhancement of farmer-centred agricultural research and extension, and agro-input industry developments were followed. The policy 'irrigation is essential for agriculture' stimulated the expansion of irrigation areas from 16.3 per cent in 1949 to 49.2 per cent in 1980. This made China well positioned to adopt a technology package-led approach for using high-yielding varieties, fertilisers and irrigation despite the institutional constraints from the collectivisation regime.

The agricultural development strategy and policy during that time focused on mobilising labour to substitute capital through a series of institutional arrangements such as the agricultural collective movement. The effect of infrastructure development and the provision of agro-inputs such as fertilisers, technology and improved seeds significantly offset the negative impact of collectivisation. In total, labour contributed 57 per cent of the agricultural growth from 1952-78 (Research Project Team of Soft Science Committee of Ministry of Agriculture 2000).

Although this agricultural strategy concentrating on food crops maintained minimum food security, the rural and national economies did not develop due to a distorted emphasis on heavy industry. This strategy mobilised capital accumulated from agriculture and allocated it to heavy industry, while farmers remained poor, and farming was under state control.

Agriculture reform in China has gone through different stages since the 1970s. From 1978-84, the major reform was to abolish the rural collective system via land reform, moving from collective land management to the 'Household Responsibility System', a privately leased land use system. The major objective of the strategy was to boost the rural economy and increase farmers' income by relaxing the controls so that farmers could have incentives to produce more, and production diversification could take place. Consequently, food crop production was greatly enhanced. Agricultural output grew at 7.7 per cent annually. The average yield of grain crops increased to 3.6 tons per hectare in 1984; an increase of 42.8 per cent compared to 1978 (Song 2008). Land reform contributed to almost 50 per cent of the agricultural growth in China (Lin 1992).
From 1985-91, the policy shifted to market reform and structural adjustment. The planning regime was still maintained for grain crop production to guarantee food supply through the state purchase system, but a quota system was introduced in 1985 in which any surplus from the quota was permitted to enter the free market, while all other agricultural products were allowed to be sold freely. Meanwhile, the rural and agricultural economic structure also changed. The share of crop production to agricultural GDP declined from 80 per cent in 1978 to 63 per cent in 1991 and the livestock share increased from 15 per cent to 26.5 per cent respectively (Song 2008).

In 1984, the Chinese Government issued a policy to promote rural industrial development. From 1984-8, the number of Township and Village Rural Enterprises (TVEs) increased from 6 million to 189 million and around one million rural people were employed (Song 2008). The rural enterprises absorbed both capital and labour from agriculture and opened the door for China's social and economic transformation.

From 1992-8, reforms focused on stabilising the land contract system and extended the land leasing right from 15 to 30 years. At the same time, the grain market system was developed by setting a protection price and grain strategic reserve, thus gradually releasing control of the grain market. Rural enterprises continued to grow at a high rate during this period under different policy supports. The rural enterprise share of the total domestic production value reached 26 per cent in 1998. It represented over 43 per cent of industry production value increase and employed 130 million rural people.

The last stage, since 1999, has been a comprehensive reform of agriculture in China. In 2004, the grain market was completely relaxed and in 2006, the agricultural tax was exempted and different subsidies for farming were introduced. Despite the shift from the collective to the household-based production system since 1978, the mobilisation of farm labour investment in agriculture has been significant.

The role of the state administrative capacity has been vital in achieving this performance. After the 1950s, the Chinese Communist Party (CCP) realised the value of the agricultural sector and considered it as a 'public sector'. It set up 
different forms of the party's agriculture and rural policy institutions, such as the Rural Work Department of the CCP's Central Committee in the 1950s for oversight, and proposed various kinds of agricultural development policies and strategies. 'Field investigation' was encouraged for all staff to understand rural China and to make suitable policies as well as obtain feedback for adjusting policies. Another such institution was the Agricultural Work Office established in the 1970s, which became the Rural Policy Research Department of the CGP's Central Committee in the 1980s. It provided strong evidence from the 'Household Responsibility System' initiated in Anhui Province for high-level decision-makers, and ultimately scaled up nationwide. This department played a significant role in pro-market reforms, and drafted the Number One Document, ${ }^{1}$ which served as a strategy and policy framework for agricultural and rural development in China in the 1980s.

Within the CCP's Central Committee, the Leading Groups Office for Rural Work (LGORW) determined all the agricultural policies. It also acted as the coordinating body, integrating different sectors' policies and continuing to develop the Number One Document. The document guided resource allocations for five years from 1982-6 as well as for yearly budgeting adjustments. Parallel to the party's agricultural policy development process, the Government's agricultural institutions also developed. Within the Government system, the Agricultural Office at different levels in the 1970s and Agricultural Commissions in the 1980s acted mainly to execute strategies and policies. Currently, agricultural policy is coordinated by the LGORW and advised on by various party and Government research bodies, such as the Policy Research Department of the CGP's Central Committee, the Research Department of the State Council, the Development Research Centre of the State Council, and the Agricultural Policy Research Centre of the Ministry of Agriculture.

China's approach is rooted in the idea of 'policy experimentation'. During the rapid reform era from the beginning of the 1980s to the beginning of the 1990s, the central Government developed an internal policy learning process by setting up ten Central Rural Reform Experimentation Tests. The tests were managed by the Rural Policy
Research Department of the Central Party Committee during the 1980s. The policy measures to tackle major problems faced by agricultural reform at that time, such as land, markets, prices, production services, etc. were first tested in the experimental areas (Office of State Council 1987). A vertical structure from central to local and a horizontal structure between organisations covering different sectors form China's agricultural policy and implementation system, ensuring that strategies and policies develop in a consistent, adjustable, and adaptive way.

The Government makes an effort to build individual capacity to train staff according to different functions. All senior leaders, such as the vice governor of a provincial district and county senior officials, have to attend full-time training for agricultural development at a university or college for at least six months to one year. Different awards have been created for those who perform successfully, and job promotion is also based on work experience at the grassroots level. A large number of senior leaders at all levels were promoted from the grassroots level, an incentive system that greatly motivates people. Successful implementation is also reinforced by party discipline that requires most of the staff who are members of the party to follow policy guidelines.

Overall, the state-led, market-driven and farmerbased model has been the central element in the success of Chinese agriculture. Thus, development of China's agriculture, as Deng Xiaoping ${ }^{2}$ said, 'first relies on the right policy development'.

\section{African policy change}

African agriculture policy since the independence period has also gone through different stages from state building with planning regimes to state weakening with market forces, but significantly most were influenced by external development interventions, and shaped by colonial experiences. From the 1960 s to the 1970 s, many newly independent African countries were influenced by socialist ideology and began to adopt state-led planning to secure food self-sufficiency. A series of measures were widely implemented, such as land reform in some East African countries, to adjust agricultural structures from traditional cash crops to food crops and to develop agricultural research and extension systems. The Green Revolution in Asia in the 1970s was widely seen as a model for 
Africa: high-yielding varieties, fertilisers and irrigation, delivered through cooperatives, etc. but success remained isolated and the 'green revolution' failed to take off in Africa (Thompson and Scoones 2009; Scoones et al. 2005).

Two different models of agricultural development were introduced to Africa in the 1970s. The state farm model was introduced by socialist states like the former Soviet Union and China to reach a scale of economy for technology adoption.

However, the former Soviet model was mainly based on its labour shortage and strong support from its own agro-industry, while China's large farm model collapsed even in China. Almost none of China-aided modern farms in Africa were successful (Xu 2011). The Integrated Rural Development Programmes (IRDPs) introduced by Western donors via provision of credit, education and health did not succeed either, except in a few short-lived cases, because these programmes were heavily dependent on high levels of government (and loan) support (Scoones et al. 2005).

Most African countries did not have a strong state with well-established administrative capacity at different levels to formulate and implement the homemade strategy and policy, or organise farmers to provide labour. The failure of Ujamaa with its efforts of collectivist agriculture in Tanzania (Boussard et al. 2006; Ibhawoh and Dibua 2003) was a typical example in this regard. On the other hand, a lack of capital hampered most African countries in their efforts to develop their infrastructure and agro-industries. Under the constant challenge of a lack of state capacity and shortage of capital, technology-based solutions such as farming system research approaches introduced by CGIAR and sustainable agricultural projects to enhance indigenous crops introduced by bilateral donor organisations in many African countries did not change the situation. Some successful stories still face the challenge of scaling up in large areas for overall sustainable agricultural improvement of smallholder production (Pretty et al. 2011). Alongside these many obstacles, limited agricultural extension services and a lack of irrigation coverage have been frequently highlighted as limiting African agricultural development.

From the 1980s and the 1990s, stagnation and deterioration of economic conditions in Africa were regarded as the result of inappropriate government policy intervention by neoliberal thinkers. Structural Adjustment Programmes (SAPs) were aggressively promoted in Africa by the international financial institutions and development agencies to get the 'state out' and bring the 'market in'. This saw Africa shift from 'state building' to 'state collapse'. In contrast with China's steady incremental reform towards market liberalisation for agriculture, the African liberalisation of markets, privatisation and restructuring of government institutions and removal of subsidies were radically and rapidly undertaken under the 'conditionality' that concessional finance would only be available for compliant countries. The privatisation and restructuring of government institutions created an immediate vacuum in the provision of services for farmers. Furthermore, the removal of farming input subsidies made the inputs no longer affordable for smallholders. Research and extension services were also reduced and the private sector was expected to fill the gap. By the 1990s it was readily apparent that the structural adjustment strategy was not delivering on its promises (Havnevik et al. 2007).

Since then there has been a growing concern about poverty and greater interest in poverty reduction being the core of development. In the context of Africa, agriculture must be the mechanism to meet this challenge. This new policy framework is well reflected in global action such as the MDGs, regional programmes such as the African Union's Comprehensive Africa Agriculture Development Programme (CAADP), and individual country Poverty Reduction Strategy Papers (PRSPs). At the same time, strengthening government capacity to support agriculture became the main element on the agenda of many donors. Africa's development is again subject to a new 'conditionality' that direct budget support is associated with the results of reviewed PRSPs. However, this new strategy has not been successful either. For example, Tanzania has one of the fastestgrowing agricultural sectors in sub-Saharan Africa. In its second poverty reduction strategy (MKUKUTA), it set a 10 per cent growth rate by 2010, but did not achieve even a 5 per cent growth rate. Ultimately, the SAPs appear to have undermined the institutional capacity of most African countries to design and implement their own poverty reduction strategies. Despite the fact that the new conditionalities are bound up 


\begin{tabular}{llllllll}
\hline & $<0.03$ ha & $\mathbf{0 . 0 3 - 0 . 0 6 7 h a}$ & $\mathbf{0 . 0 6 7 - 0 . 1 1 h a}$ & $\mathbf{0 . 1 1 - 0 . 2 h a}$ & $\mathbf{0 . 2 - 0 . 2 7 h a}$ & $\mathbf{0 . 2 7 - 0 . 6 7 h a}$ & $\boldsymbol{> 0 . 6 7 h a}$ \\
\hline $\begin{array}{l}\text { No of } \\
\text { households }\end{array}$ & 1,330 & 2,084 & 2,057 & 813 & 488 & 988 & 197 \\
Ratio & $16.71 \%$ & $26.19 \%$ & $25.85 \%$ & $10.22 \%$ & $6.13 \%$ & $12.42 \%$ & $2.48 \%$ \\
\hline
\end{tabular}

Source Investigation in 455 villages in China in 2005 by the authors.

with enhancing the role of the state, the context of enhancing the state's role is very much influenced by experiences from the West, rather than African perspectives or successful cases elsewhere. The New Partnership for Africa's Development (NEPAD) and the New Alliance for Food Security and Nutrition with its long list of ambitious targets, risk repeating past mistakes (Scoones 2012; Moyo 2006).

Despite this, Africa has achieved some individual successes in agricultural development. For example, through a combination of agricultural extension and marketing support, input deliveries and credit, governments in east and southern Africa achieved a series of smallholder production surges lasting 10-20 years (GabreMadhin and Haggblade 2004). West African agricultural successes have also been noted (Wiggins and Leturque 2010). With policy reform in rice milling and marketing, Malian rice production has more than tripled since 1985 (Diarra et al. 2000). Moreover, studies in eight African countries found evidence where farms or regions have achieved crop yields far above the national average (Djurfeldt et al. 2005). However, the challenge now is to scale up those activityspecific successes into sustained, system-wide improvements. Since both Africa and Chinese experience centres on smallholder production, sharing experience through development cooperation efforts is a priority.

\section{Smallholder agricultural production and productivity in China and Africa}

China's agriculture is predominantly based on a smallholder farming structure. In 2007, there were 255.22 million smallholder family farms operating 116.273 million hectares, accounting for 95.6 per cent of total arable land in the country, whereas 1,885 large state farms operate only 5.3 million hectares of arable land (NBSC 2008). As Table 1 indicates, over 50 per cent of Chinese farmers only have from $0.03-0.11$ hectares of arable land per capita on average. The share of the farms with a size exceeding 0.67 hectares per capita is only 2.48 per cent.

The question is how smallholder livelihoods in China are maintained under such small-scale conditions. Productivity is achieved through an intensive family farming system. In most parts of China, multiple cropping is widely practised and mixed crop-livestock systems are common. Smallholder agriculture in China is very labourintensive, although some of this work has now been taken over by machines. Chinese smallholders widely use improved seed varieties and fertilisers. Settlement patterns and land use in rural China also contribute to agricultural development. Except in mountainous areas, villages are usually nucleated and arable land belonging to different smallholders is relatively concentrated. This helps the development of largescale commercial crop clusters such as maize clusters in northern China and rice clusters in southern China. This also favours the economic use of joint services such as irrigation, extension, harvesting and marketing services provided by the state. Currently, with an increasing labour movement out of agriculture, mechanisation has gradually taken over heavy farm work such as ploughing, planting and harvesting. Mechanisation is not normally done through individual family farms, but is provided by private services. Public goods provisions for smallholders such as irrigation, improved seed, research and extension services and agro-inputs are provided by the state.

All these factors make China's smallholder agricultural productivity much higher than African smallholder productivity both in terms of land and labour, as Table 2 indicates.

Despite the existence of large commercial farms in Africa, over 72 per cent of the total population live in rural areas and 70 per cent are engaged in agriculture (Moussa 2002). Similar to China, 


\begin{tabular}{llll}
\hline & Zambia & Tanzania & China \\
\hline Household & 108 & 454 & 110 \\
Population & 756 & 1996 & 440 \\
Average arable land (ha/household) & 3.64 & 1.19 & 0.4 \\
Average maize area (ha/household) & 1.365 & 0.98 & 0.1 \\
Fertiliser expenditure (USD/ha) & 1.776 & 0 & 266.3 \\
Pesticide costs (USD/ha) & 0.66 & 0.27 & 110.9 \\
Seed costs (USD/ha) & 10.53 & 5.90 & 55.5 \\
Hiring costs (USD/ha) & 1.62 & 18.87 & 11.1 \\
Machinery costs (USD/ha) & 0 & 0 & 177.5 \\
Herbicide costs (USD/ha) & 0 & 0 & 26.6 \\
Irrigation costs (USD/ha) & 0 & 0 & 199.7 \\
Total input (USD) & 14.59 & 25.04 & 847.6 \\
Output (kg/ha) & 430 & 580 & 6750 \\
Output (USD/ha) & 86 (0.2) & 133.4 (0.23) & 1250 (0.186) \\
Subsides (USD/ha) & 0 & 0 & 0 \\
Labour productivity & 215 & 290 & 349 \\
Land productivity & 430 & 580 & 6750 \\
\hline & & & \\
\hline
\end{tabular}

Source Village surveys taken in Tanzania and Zambia by author in 2009.

smallholders dominate Africa's agriculture although the average size of African smallholdings is larger than that of Chinese smallholdings. Different from the Chinese case, most African agricultural smallholder production is extensive. Even under favourable climatic conditions in most of sub-Saharan Africa, multiple cropping systems are rarely seen. Low levels of crop yields push African smallholders to expand cultivated areas, and labour shortages appear due to a lack of capital to buy machinery. However, expansion of arable land has stagnated in recent years, indicating that land frontiers may have been reached. The result is mounting population pressure and declining farm size (Diao et al. 2010). Even with land-rich conditions, most sub-Saharan African countries have not developed labour-saving agricultural systems due to the property rights regimes that constrain access to land. In other countries, mechanical and animal draft innovations are limited by poor access to markets and a limited range of appropriate and affordable technologies for individual farm conditions (Gordon 2008).
While land expansion has dominated past growth, there is an extensive literature identifying the potential for intensifying food crop production in Africa (Diao et al. 2010). In fact, farmland from different smallholders in rural sub-Saharan Africa is often dispersed across a relatively large area and there are few with large irrigation schemes. This makes land preparation, joint labour use and mechanised harvesting more costly, and also increases transport costs. Unlike rural China, communitybased irrigation facilities collecting rainfall or using water from small rivers are relatively scarce in sub-Saharan Africa (although see Reij and Scoones 1996). Lack of use of improved seed and fertilisers has been considered the major constraint to agricultural development in subSaharan Africa. Fertiliser use in China increased from $158 \mathrm{~kg} /$ hectare in 1980 to $323 \mathrm{~kg} /$ hectare in 2002 while it only increased from $6.3 \mathrm{~kg} /$ hectare to $6.8 \mathrm{~kg} /$ hectare in sub-Saharan Africa (Li et al. 2010).

In sub-Saharan Africa, the area under irrigation is about 9 million hectares, accounting for only 
5 per cent of the total arable land area. Uganda, for example, has some of the richest water resources on the continent, but the arable land area with access to irrigation facilities only accounts for 0.1 per cent of the total. What is more, the cost of developing irrigated arable land in sub-Saharan Africa is very high. According to a research report of the FAO (1995), the cost of water resource development for medium and large irrigation facilities is US $\$ 8,300$ per hectare in sub-Saharan Africa, plus the cost of related infrastructure construction, such as roads, housing, cable and public service facilities; the cost of which is about another US\$18,300 per hectare (Rosegrant et al. 2002).

\section{The politics of agricultural policy}

Agriculture has been developed in China and Africa under different historical and political, social and economic conditions, and Africa should be cautious when reviewing the Chinese experience. There are nevertheless some important lessons to be drawn from the Chinese experience that could be useful in determining the future of some agricultural policies in African states. Much of this centres on the politics of policy, and the importance of a consistent, long-term, learning approach, rooted in local contexts, avoiding sudden change and inappropriate external interventions.

In China, a consistent agriculture-centred development strategy and staple food crop-led agricultural development policy, honed through an incremental learning process, significantly shaped smallholder agriculture. Another lesson from China stems from the steady transformation towards a market system ensured by the provision of irrigation, improved seed and fertilisers, and market facilities provided by the state, which enabled smallholders to gain access to the services at low cost. In contrast, despite the consensus reached on the vital role of agricultural policy in Africa, most countries have not been able to develop their own localised strategies. Building a food-based agriculture system takes time and must be accompanied by comprehensive support to assist appropriate new technologies to emerge. This includes re-investing in agricultural education, research institutes and experiment stations as well as a modern extension service. African perspectives on agricultural development have been largely interrupted by various external influences. As a result, many well-intentioned support programmes have not been well integrated with the African smallholder agricultural system. At the same time, African countries have not been able to develop their own governmental capacity to provide the necessary support services for smallholders. Thus, smallholders have become a victim of marketisation and privatisation.

China's agricultural development experiences also suggest that the effect of agricultural strategy and policy changes depend on the state's capacity to implement them on the one hand, and on the other hand, whether the policy is suitable for smallholders and their social, economic and environmental conditions. China's agricultural development policies have always focused on providing incentives to sustain a landsaving growth path, while in most African countries, the constraints derived from land tenure and service provision for developing either labour-saving or land-saving strategies have not been eliminated or reduced. Land tenure and lack of mechanisation constrain relatively land-rich countries from transforming smallholdings into commercial farms. They also largely account for the low adoption of improved seeds. In other words, policy issues cannot be considered simply as technical problems such that efficiency problems can be solved by technocratic solutions. Nor has it been effective in Africa to try to produce more favourable agricultural environments by encouraging external interventions led by big objectives and big business. The most important consideration is how to put the real needs of smallholders at the top of those big policies and plans.

Unlike China's pro-smallholder agricultural policy and institutional capacity, most African countries lack a political environment in which smallholders can exert their influence, while large-scale farming has stronger lobbies in government; perhaps increasingly so with the rush to foreign land investment in recent years (Hall 2011). Even in those countries which have developed a strong pro-agriculture policy, poor delivery capacity has constrained policy implementation (Poulton 2012).

As noted already, the key experience from China's agricultural development is a consistent policy that focuses on productivity-based staple crop-led agricultural development. Over time, 
despite the efforts made by many African countries towards self-sufficiency in food crop production and knowing that staple-led agricultural growth can generate effective growth and poverty reduction, past growth in staple foods has typically arisen from land expansion and there seems to have been little attention given to the food sector or in changing established methods of production (Diao et al. 2010). Various kinds of external supports did not help Africa effectively develop its own agricultural development process, and consequently African countries have remained trapped in agricultural stagnation.

Thus, China's experience suggests that for the countries with a majority of smallholdings, the development of agriculture requires consistent context-based strategies. With a dominant staple crop rural structure, agricultural development can be staple crop-led. Above all, market reform should be gradual so that smallholders will not be put into a 'market trap' under market reform.

Of course this is not to suggest that large-scale farming for cash crops and export materials should be stopped, but it is clear that this single structural track in agriculture is insufficient to earn investment capital for wider state development. The China case shows that both food-based systems and large-scale agriculture can exist side by side and that many mutual benefits can be derived from their coexistence. A shift in emphasis towards sustaining and improving the food-based smallholder systems in Africa can be

\section{Notes}

* The authors would like to thank James Putzel, Henry Berstein, David Rohrbach and Hans P. Binswanger for their useful comments on the original article. Special thanks to Ian Scoones for his comments and revisions.

1 A key policy document published annually often focusing on farmers, agriculture and rural areas. It is always the first policy document issued by the Chinese Communist Party's Central Committee every year. an inexpensive complement to the ongoing cash crop economies. A symbiosis that fits the African reality needs to be configured and strongly maintained by state policy and programmes. The state has a clear role to play. As in China, food systems are a public as well as a private good.

However, Africa should still be very cautious about what to learn from China's successful experience in agricultural development. For example, China's long-standing food productionbased agricultural policy has achieved national food security and increased food exports while farmers' incomes have grown at a slower rate. Furthermore, China's agricultural production system has featured 'high input - high output' production patterns that have made an important contribution to food security, but many have had irreversible impacts on the environment and natural resources. Africa of course cannot simply copy China's experience, but there are experiences to be learned from.

With diverse internal situations on the continent, in order to successfully learn from China's experience in agricultural development, African countries should carefully identify and make adjustments to China's experience in order to adapt to local and regional situations; just as China has done throughout its long history. Above all, African nations need to make their own agricultural plans and continue to develop the human and fiscal resources to implement them, requiring a strong state commitment and an effective smallholder farming lobby.

2 In Deng's talks with responsible persons on the Planning Commission, afterwards renamed as the Commission of Development and Reform, he mentioned that agricultural development relied on policy first and on science and technology second. This took place on 26 July 1982 and put into order a 'ten years preparation for another ten years' on 14 October 1982. 


\section{References}

Adams, W.M. and Mortimore, M.J. (1997)

'Agricultural Intensification and Flexibility in the Nigerian Sahel', The Geographical Journal, Environmental Transformation in Developing Countries 163.2: 150-60

Baum, W. and Lejeune, M. (1986) Partners against Hunger, Washington DC: World Bank for the GGIAR

Boussard, J-M.; Daviron, B.; Gérard, F. and Voituriez, T. (2006) Food Security and Agricultural Development in Sub-Saharan Africa: Building a Case for More Support, Rome: CIRAD for FAO

CDSG (China-DAC Study Group) (2011) Economic Transformation and Poverty Reduction: How it Happened in China, Helping it Happen in Africa, Beijing: China Fiscal and Economic Press

Deng, L. (1984) Economic System Reform in Contemporary China, Beijing: China Social Sciences Press

Diao, X.; Hazell, P. and Thurlow, J. (2010) 'The Role of Agriculture in African Development', World Development 38.10: 1375-83

Diarra, S.B.; Staatz, J.M.; Bingen, R.J. and Dembélé, N.N. (2000) 'The Reform of Rice Milling and Marketing in the Office du Niger: Catalyst for an Agricultural Success Story in Mali', Staff Paper 99-26, East Lansing: Department of Agricultural Economics, Michigan State University

Djurfeldt, G.; Holmén, H.; Jirström, M. and Larsson, R. (eds) (2005) The African Food Crisis: Lessons from the Asian Green Revolution, Oxford: CABI

FAO (1995) Irrigation Development Costs, Rome: Food and Agriculture Organization

Gabre-Madhin, E.Z. and Haggblade, S. (2004) 'Successes in African Agriculture: Results of an Expert Survey', World Development 32.5: 745-66

Gordon, H. (2008) 'Agricultural Productivity and Shared Growth', in R.J. Utz (ed.), Sustaining and Sharing Economic Growth in Tanzania, Washington DC: World Bank

Hall, R. (2011) 'Land Grabbing in Africa and the New Politics of Food', FAC Policy Brief 41, Brighton and Nairobi: Future Agricultures Consortium

Havnevik, K.; Bryceson, D.; Birgegard, L.; Matondi, P. and Beyene, A. (2007) African Agriculture and the World Bank Development or Impoverishment?, Stockholm: Sweden by Elanders Sverige AB
Huang, J. (2008) Institutional Changes and Sustainable Development: China Agriculture and Rural Areas in the Past Thirty Years, Shanghai, China: Gezhi Publishing House and Shanghai People's Publishing House

Ibhawoh, B. and Dibua, J.I. (2003)

'Deconstructing Ujamaa: The Legacy of Julius Nyerere in the Quest for Social and Economic Development in Africa', African Association of Political Science 8.1: 59-83

Li, X.; Qi, G.; Tang, L.; Zhao, L.; Jin, L.; Guo, Z. and Wu, J. (2010) Small Farmer-based Agricultural Development: Comparative Analysis of China and Africa, Beijing: Social Sciences Academic Press

Lin, Y. (1992) Rural Reforms and Agricultural Growth in China, Shanghai: Shanghai Joint Publishing Company and Shanghai People's Press

Moussa, S.Z. (2002) 'Technology Transfer for Agricultural Growth in Africa', Economic Research Papers 72, Tunis-Belvedère, Tunisia: African Development Bank

Moyo, S. (2006) 'Africa's Agrarian

Transformation: The Efficacy of the NEPAD Agriculture Strategy', in J.O. Adésínà, Yao Graham and A. Olukoshi (eds), Africa and Development: Challenges in the New Millennium, London: Zed Books

NBSC (National Bureau of Statistics of China) (2008) China Statistical Yearbook, Beijing: China Statistics Press

NBSC (National Bureau of Statistics of China) (1999) Comprehensive Development of Agriculture, Forestry, Animal Husbandry and Fishery: Fifth Report of Series Analysis Report of 50 Years of New China, www.stats.gov.cn/tjfx/ztfx/ xzgwsnxlfxbg/t20020605_21422.htm (accessed 12 April 2013)

Office of State Council (1987) Announcement of Distribution of Proposal on Rural Reform Experimental Area Proposed by Rural Development Centre of State Council, Beijing: Office of State Council

Oya, C. (2010) 'Agro-Pessimism, Capitalism and Agrarian Change: Trajectories and Contradictions in Sub-Saharan African', in V. Padayachee (ed.), The Political Economy of Africa, London: Routledge

Poulton, C. (2012) Democratisation and the Political Economy of Agricultural Policy in Africa, FAC

Working Paper 042, Brighton and Nairobi: Future Agricultures Consortium

Pretty, J.; Toulmin, C. and Williams, S. (2011)

'Sustainable Intensification in African 
Agriculture', International Journal of Agricultural Sustainability 9.1: 5-24

Ravallion, M. (2009) 'Are there Lessons for

Africa from China's Success Against Poverty?', World Development 37.2: 303-13

Reij, I and Scoones, I. (eds) (1996) Sustaining the Soil: Indigenous Soil and Water Conservation in Africa, London: Earthscan

Research Project Team of Soft Science Committee of Ministry of Agriculture (2000) New Phase of Agricultural Development in China, Beijing: China Agricultural Press

Rosegrant, M.; Cai, X.; Cline, S. and Nakagawa, N. (2002) The Role of Rainfed Agriculture in the Future of Global Food Production, Environment and Production Technology Division Discussion Paper 90, Washington DC: International Food Policy Research Institute (IFPRI)

Scoones, I. (2012) A New Alliance for Food Security, or a Two-Track Africa?, blog, www.futureagricultures.org/blog/entry/a-new-alliance-forfood-security-or-a-two-track-africa (accessed 10 March 2013)

Scoones, I.; Devereux, S. and Haddad, L. (2005) 'Introduction: New Directions for African Agriculture', IDS Bulletin 36.2: 1-12
Song, H. (2008) Thirty Years of China Rural Reform, Beijing: China Agricultural Press

Thompson, J. and Scoones, I. (2009) 'Addressing the Dynamics of Agri-Food Systems: An Emerging Agenda for Social Science Research', Environmental Science and Policy 12.4: 386-97

Tiffen, M.; Mortimore, M. and Gichuki, F. (1994) More People, Less Erosion: Environmental Recovery in Kenya, London: John Wiley

Wiggins, S. and Leturque, H. (2010) Helping Africa to Feed Itself: Promoting Agriculture to Reduce Poverty and Hunger, FAC Occasional Paper, Brighton and Nairobi: Future Agricultures Consortium

World Bank (2007) 'Agriculture for Development', World Development Report, Washington DC: World Bank

Wu, H. (1988) 'The Yield Unit Issue of Crops in Qing Dynasty of China', Agricultural Archaeology 1: 57-64

Xu, X. (2011) 'Reshaping the International Development Discourse', Journal of China Agricultural University (Social Science Edition) 28.4: 22-3 